\title{
Wheat Straw as a Bio-Sorbent for Arsenate, Chromate, Fluoride, and Nickel
}

\author{
Aurora Romar-Gasalla ${ }^{1}$, Gustavo F. Coelho ${ }^{2}$, Juan Carlos Nóvoa-Muñoz ${ }^{3}$ (iD, \\ Manuel Arias-Estévez ${ }^{3}$ (iD), María J. Fernández-Sanjurjo ${ }^{1}$, Esperanza Álvarez-Rodríguez ${ }^{1}$ \\ and Avelino Núñez-Delgado 1,* \\ 1 Department of Soil Science and Agricultural Chemistry, Engineering Polytechnic School, Campus Lugo, \\ Universidade de Santiago de Compostela, 27002 Lugo, Spain; auriroga@gmail.com (A.R.-G.); \\ mf.sanjurjo@usc.es (M.J.F.-S.); esperanza.alvarez@usc.es (E.A.-R.) \\ 2 Center for Agricultural Sciences, Marechal Cândido Rondon, Paraná, Rua Pernambuco, 1777, CEP 85960-000, \\ State University of West Paraná, 85819-110 Cascavel, Brazil; facebookdescarga@gmail.com \\ 3 Department of Plant Biology and Soil Science, Faculty of Sciences, Campus Ourense, Universidade de Vigo, \\ 32004 Ourense, Spain; edjuanca@uvigo.es (J.C.N.-M.); mastevez@uvigo.es (M.A.-E.) \\ * Correspondence: avelino.nunez@usc.es; Tel.: +34-982-823-140
}

Received: 2 July 2017; Accepted: 7 September 2017; Published: 9 September 2017

\begin{abstract}
Batch-type experiments were used to study $\mathrm{As}(\mathrm{V}), \mathrm{Cr}(\mathrm{VI}), \mathrm{F}^{-}$, and $\mathrm{Ni}^{2+}$ sorption/desorption on wheat straw. For the lowest concentration added $\left(0.5 \mathrm{mmol} \cdot \mathrm{L}^{-1}\right)$, the sorption sequence was $\mathrm{F}^{-}>\mathrm{Ni}^{2+}>\mathrm{Cr}(\mathrm{VI})>>\mathrm{As}(\mathrm{V})(93 \%, 61 \%, 29 \%, 0.3 \%)$, but changed to $\mathrm{Ni}^{2+}>\mathrm{F}^{-}>\mathrm{Cr}(\mathrm{VI})>>\mathrm{As}(\mathrm{V})$ when 3.0 and $6.0 \mathrm{mmol} \cdot \mathrm{L}^{-1}$ were added (with $65 \%, 54 \%, 25 \%, 0 \%$, and $68 \%, 52 \%, 27 \%, 0 \%$ sorption, respectively). Overall, $\mathrm{As}(\mathrm{V})$ showed the lowest sorption, whereas it was $25-37 \%$ for $\mathrm{Cr}(\mathrm{VI}), 61-68 \%$ for $\mathrm{Ni}^{2+}$, and $52-93 \%$ for $\mathrm{F}^{-}$. For $\mathrm{As}(\mathrm{V})$, $\mathrm{pH}$ in the equilibrium solution was always above the $\mathrm{pH}$ of the point of zero charge $\left(\mathrm{pH}_{\mathrm{PZC}}\right)$ for wheat straw, decreasing sorption efficiency. For $\mathrm{Cr}(\mathrm{VI}), \mathrm{pH}$ was below $\mathrm{pH}_{\mathrm{PZC}}$, but not enough to reach high sorption. For $\mathrm{F}^{-}, \mathrm{pH}$ in the equilibrium was above $\mathrm{pH}_{\mathrm{PZC}}$, which could reduce sorption. For $\mathrm{Ni}^{2+}, \mathrm{pH}$ in the equilibrium was always below $\mathrm{pH}_{\mathrm{PZC}}$, which made sorption difficult. The satisfactory fitting of $\mathrm{Cr}(\mathrm{VI}), \mathrm{F}^{-}$, and $\mathrm{Ni}^{2+}$ data to the Freundlich model suggests multilayer-type adsorption. Desorption was high for $\mathrm{F}^{-}$, whereas $\mathrm{Ni}^{2+}$ showed the lowest desorption. This research could be especially relevant when focusing on the use of wheat straw as a bio-sorbent, and in cases where straw mulching is used.
\end{abstract}

Keywords: $\mathrm{As}(\mathrm{V}) ; \mathrm{Cr}(\mathrm{VI}) ; \mathrm{F}^{-} ; \mathrm{Ni}^{2+}$; retention/release; straw

\section{Introduction}

Public health issues, phytotoxicity and overall pollution concerns have been related to $\mathrm{As}(\mathrm{V})[1,2]$, $\mathrm{Cr}(\mathrm{VI})[3,4], \mathrm{F}[5,6]$, and $\mathrm{Ni}[7]$.

To fight heavy metal, metalloid, and $\mathrm{F}^{-}$pollution, different waste and by-products have been studied as bio-sorbents [8,9], including mussel shell [10-12] and wood industry waste [13]. As indicated by Malik et al. [14], some cellulosic materials (as wheat straw) can be effective low-cost sorbents. In addition, 315.9 million tons per year of agricultural residue are generated in the European Union [15], and total (world basis) cereal straw generation is estimated to be 1580 million tons per year [16], which should stimulate its recycling [17].

Previous research has aimed at straw as a means for reducing erosion in sloped soils affected by forest fires [18-20], or as a sorbent to fight heavy metals pollution [21-23]. In addition, Rao et al. [24] found that straw mulching could reduce the loss of heavy metals in runoff. We have previously studied cadmium, copper, and lead sorption on wheat straw [17], with a main focus on sustainability in vineyards. However, as far as we know, no previous studies have dealt with $\mathrm{As}(\mathrm{V}), \mathrm{Cr}(\mathrm{VI}), \mathrm{F}^{-}$ 
and $\mathrm{Ni}^{2+}$ retention on wheat straw, adding concentrations up to $6 \mathrm{mmol} \cdot \mathrm{L}^{-1}$ to each one. This could be relevant, taking into account that wheat straw recycled in agriculture (or used to reduce soil erosion) could facilitate temporary retention of different elements by contacting the sorbent when transported within percolating waters or runoff, thus alleviating peaks of concentration associated with pollution risks.

In light of this, the objective of this work was to study $\mathrm{As}(\mathrm{V}), \mathrm{Cr}(\mathrm{VI}), \mathrm{F}^{-}$, and $\mathrm{Ni}^{2+}$ retention/release on wheat (Triticum aestivum) straw, adding up to $6 \mathrm{mmol} \cdot \mathrm{L}^{-1}$ of each element. The results of the study could provide useful information regarding the potential of wheat straw to immobilize these anions and cations, which could help to reduce the eventual risks of soil and water contamination.

\section{Materials and Methods}

\subsection{Characteristics of the Wheat Straw}

The wheat straw used was from a local provider (Cospeito, Lugo, Spain). It was dried, milled, and sieved (not washed), using particles between 2.0 and $0.5 \mathrm{~mm}$ (representing $95 \%$ of the initial weight before milling) for analyses. Samples corresponding to the same batch of the wheat straw here used were previously characterized by Coelho et al. [17]. Its main characteristics are presented in Supplementary Materials.

\subsection{Sorption/Desorption Experiments}

Wheat straw samples ( $2.5 \mathrm{~g}$ each) were weighed and added with $30 \mathrm{~mL}$ of a $1 \mathrm{M} \mathrm{NaNO}_{3}$ solution (used as background electrolyte to control ionic strength), with increasing individual concentrations $\left(0.5,1.5,3.0\right.$ and $\left.6.0 \mathrm{mmol} \cdot \mathrm{L}^{-1}\right)$ of one of the following substances: $\mathrm{As}(\mathrm{V}), \mathrm{Cr}(\mathrm{VI}), \mathrm{F}^{-}$or $\mathrm{Ni}^{2+}$, respectively, prepared from $\mathrm{Na}_{2} \mathrm{HAsO}_{4}, \mathrm{~K}_{2} \mathrm{Cr}_{2} \mathrm{O}_{7}, \mathrm{KF}$ (Panreac, Barcelona, Spain), and $\mathrm{Ni}\left(\mathrm{NO}_{3}\right)_{2} \cdot 6 \mathrm{H}_{2} \mathrm{O}$ (Sigma-Aldrich, St. Louis, MO, USA). These suspensions were stirred for $24 \mathrm{~h}$, centrifuged (at $4000 \mathrm{rpm}$ for $15 \mathrm{~min}$, with equivalence to $6167 \times g)$, and filtered through acid washed paper with a pore size of $2.5 \mu \mathrm{m}$. On the filtrate, As, Cr, and Ni were determined by means of ICP-MS (Varian 820-MS, Varian, Palo Alto, CA, USA); F was quantified by using an ion selective electrode (Orion Research, Jacksonville, FL, USA), with the addition of a total ionic strength adjuster and the buffer TISAB IV; $\mathrm{pH}$ was measured by using a pH-meter (model 2001, Crison Instruments, Barcelona, Spain); dissolved organic carbon (DOC) was determined by UV-visible spectrometry (UV-1201, Shimadzu, Kyoto, Japan). Sorbed As(V), $\mathrm{Cr}(\mathrm{VI}), \mathrm{Ni}^{2+}$, and $\mathrm{F}^{-}$were calculated as the difference between added concentration of each element and the concentration remaining in the $24 \mathrm{~h}$ equilibrium solutions.

Desorption was determined after sorption experiments, adding $30 \mathrm{~mL}$ of $0.01 \mathrm{M} \mathrm{NaNO}_{3}$ to each sample, then stirring $(24 \mathrm{~h}$ ), centrifuging ( $4000 \mathrm{rpm}$ for $15 \mathrm{~min}$, equivalent to $6167 \times \mathrm{g}$ ), and filtering through acid washed paper. As, $\mathrm{Cr}, \mathrm{F}, \mathrm{Ni}, \mathrm{pH}$, and DOC, were determined as above. All determinations were carried out in triplicate.

\subsection{Data Analyses}

Descriptive statistics, as well as adjustment to adsorption models, were carried out by means of the statistical package SPSS 21 (IBM, New York, NY, USA).

Equation (1) was used to calculate adsorbed quantities $\left(\mathrm{Q}_{\mathrm{e}}\right)$ for $\mathrm{As}(\mathrm{V}), \mathrm{Cr}(\mathrm{VI}), \mathrm{F}^{-}$, and $\mathrm{Ni}^{2+}$ :

$$
\mathrm{Q}_{\mathrm{e}}=\mathrm{V}\left(\mathrm{C}_{0}-\mathrm{C}_{\mathrm{f}}\right) / \mathrm{m}
$$

where $Q_{e}=$ quantity of each element adsorbed at the equilibrium $\left(\mathrm{mg} \cdot \mathrm{g}^{-1}\right), \mathrm{m}=$ mass of wheat straw used as adsorbent $(\mathrm{g}), \mathrm{C}_{0}=$ initial concentration in solution for each element $\left(\mathrm{mg} \cdot \mathrm{L}^{-1}\right), \mathrm{C}_{\mathrm{f}}=$ final concentration in solution for each element $\left(\mathrm{mg} \cdot \mathrm{L}^{-1}\right)$, and $\mathrm{V}=$ volume of solution (L).

The fitting of sorption data to the Langmuir and Freundlich models was investigated. However, fitting to the Langmuir model was not possible due to error values being too high for adjustment. 
Equation (2) corresponds to the Freundlich model:

$$
\mathrm{Q}_{\mathrm{eq}}=\mathrm{K}_{\mathrm{F}} \mathrm{C}_{\mathrm{e}}^{1 / \mathrm{n}}
$$

where $Q_{\text {eq }}=$ quantity adsorbed of each element $\left(\mathrm{mmol} \cdot \mathrm{kg}^{-1}\right), \mathrm{K}_{\mathrm{F}}=$ Freundlich constant (which is related to the energy of adsorption), $C_{e}=$ concentration of each element at the equilibrium $\left(\mathrm{mmol} \cdot \mathrm{L}^{-1}\right)$, and $n=$ constant related to the adsorption intensity.

\section{Results and Discussion}

\section{1. $\mathrm{As}(\mathrm{V}), \mathrm{Cr}(\mathrm{VI}), \mathrm{F}^{-}$, and $\mathrm{Ni}^{2+}$ Sorption as a Function of Concentrations Added}

Figure 1 shows that sorption $\left(Q_{e}\right)$ for the lowest initial concentration added $\left(0.5 \mathrm{mmol} \cdot \mathrm{L}^{-1}\right)$ was in the order $\mathrm{F}>\mathrm{Ni}>\mathrm{Cr}>>$ As, with values of $4.6,3.0,1.4$, and $0.01 \mathrm{mmol} \cdot \mathrm{kg}^{-1}$, corresponding to percentage sorption (with respect to the concentration added) from $93.4 \%$ to $0.3 \%$ (Table 1 ). When the highest initial concentrations $\left(3.0\right.$ and $6.0 \mathrm{mmol} \cdot \mathrm{L}^{-1}$ ) were added, the sequence changed to $\mathrm{Ni}>\mathrm{F}>\mathrm{Cr}>>$ As. The specific values for $3.0 \mathrm{mmol} \cdot \mathrm{L}^{-1}$ added were $19.5,16.0,7.6$, and $0.0 \mathrm{mmol} \cdot \mathrm{kg}^{-1}$, corresponding to percentage sorption from $65.2 \%$ to $0 \%$. For $6 \mathrm{mmol} \cdot \mathrm{L}^{-1}$ added, the values were 40.2 , $31.0,16.4$, and $0.0 \mathrm{mmol} \cdot \mathrm{kg}^{-1}$, corresponding to percentage sorption from $67.5 \%$ to $0 \%$. The scale of electronegativity of the elements investigated ( $\mathrm{F}>\mathrm{As}>\mathrm{Ni}>\mathrm{Cr}$ ) was not coincident with the sorption sequences found for any of the concentrations added.

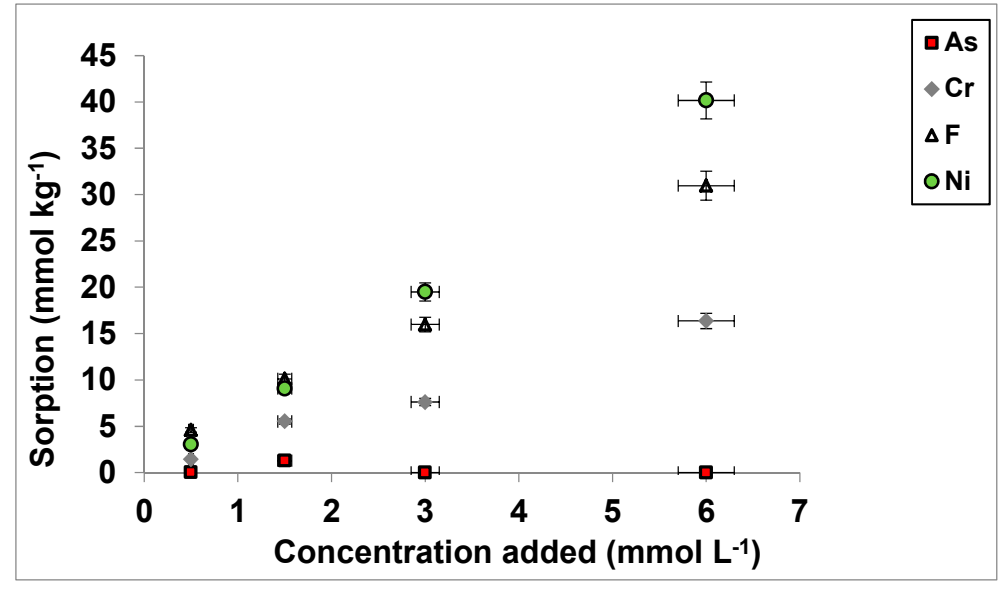

Figure 1. $\mathrm{As}(\mathrm{V}), \mathrm{Cr}(\mathrm{VI}), \mathrm{F}^{-}$, and $\mathrm{Ni}^{2+}$ sorption $\left(\mathrm{mmol} \cdot \mathrm{kg}^{-1}\right)$ for different concentrations added $\left(\mathrm{mmol} \cdot \mathrm{L}^{-1}\right)$ of each element. Average values (with error bars) for 3 replicates, with coefficients of variation always $<5 \%$.

Table 1. As, $\mathrm{Cr}$, F, and Ni percentage sorption on wheat straw for different concentrations added $\left(\mathrm{C}_{0}\right)$ $\left(0,0.5,1.5,3.0\right.$, and $\left.6.0 \mathrm{mmol} \cdot \mathrm{L}^{-1}\right)$.

\begin{tabular}{ccccc}
\hline $\mathrm{C}_{\mathbf{0}}$ & $\mathbf{0 . 5}$ & $\mathbf{1 . 5}$ & $\mathbf{3 . 0}$ & $\mathbf{6 . 0}$ \\
\hline \multicolumn{5}{c}{ Sorption (\%) } \\
\hline $\mathrm{As}(\mathrm{V})$ & 0.3 & 8.5 & 0 & 0 \\
$\mathrm{Cr}(\mathrm{VI})$ & 29.1 & 36.9 & 25.5 & 27.4 \\
$\mathrm{~F}^{-}$ & 93.4 & 68.4 & 54.1 & 52.3 \\
$\mathrm{Ni}^{2+}$ & 61.3 & 60.7 & 65.2 & 67.5 \\
\hline
\end{tabular}

Note: Average values for 3 replicates, with coefficients of variation always $<5 \%$.

Table 1 and Figure 1 show that the lowest sorption corresponded to As(V), especially when the highest $\mathrm{As}(\mathrm{V})$ concentrations ( 3 and $6 \mathrm{mmol} \cdot \mathrm{L}^{-1}$ ) were added. Regarding $\mathrm{Cr}(\mathrm{VI})$, rather low sorption 
percentages were found, with the highest (36.9\%) being obtained when $1.5 \mathrm{mmol} \cdot \mathrm{L}^{-1}$ was added, then declining with increasing concentrations. $\mathrm{F}^{-}$showed rather high sorption results, although with decreasing percentages (from $93.4 \%$ to $52.3 \%$ ) as a function of increasing $\mathrm{F}^{-}$concentrations added. $\mathrm{Ni}^{2+}$ showed notable sorption and an opposite trend to that of $\mathrm{F}^{-}$, with sorption percentage increasing when the highest $\mathrm{Ni}^{2+}$ concentrations $\left(3\right.$ and $6 \mathrm{mmol} \cdot \mathrm{L}^{-1}$ ) were added. We have previously studied [10-13,25-28] the effects of different concentrations, $\mathrm{pH}$, incubation time, and other variables on $\mathrm{As}(\mathrm{V}), \mathrm{Cr}(\mathrm{VI}), \mathrm{F}^{-}$, and $/$or $\mathrm{Ni}^{2+}$ retention on other sorbent materials, but it should be also performed for wheat straw in future works.

It must be taken into account that $\mathrm{As}(\mathrm{V}), \mathrm{Cr}(\mathrm{VI})$, and $\mathrm{F}$ are present in solution in the form of anions, whereas nickel is in cationic form $\left(\mathrm{Ni}^{2+}\right)$. $\mathrm{F}$ in solution is found in the form of fluoride $\left(\mathrm{F}^{-}\right)$[29], and $\mathrm{Cr}(\mathrm{VI})$ is an oxyanion that can be found as $\mathrm{HCrO}_{4}{ }^{-}, \mathrm{CrO}_{4}{ }^{2-}$, and $\mathrm{Cr}_{2} \mathrm{O}_{7}{ }^{2-}$ depending on the $\mathrm{pH}[30]$.

Low $\mathrm{As}(\mathrm{V})$ sorption efficiency can be related to the solution $\mathrm{pH}$. In fact, $\mathrm{pH}$ value was between 7.0 and 7.6 in the equilibrium solution when the various $\mathrm{As}(\mathrm{V})$ concentrations were added (Table 2), always being above the $\mathrm{pH}_{\text {PZC }}$ value for wheat straw (6.68), implicating a predominance of negative charges on the surface of the adsorbent, thus decreasing $\mathrm{As}(\mathrm{V})$ sorption efficiency. For $\mathrm{As}(\mathrm{V})$, sorption was low at low added concentrations, and there was no $\mathrm{As}(\mathrm{V})$ sorption at higher added concentrations. According to Mohan and Pittman [31], $\mathrm{As}(\mathrm{V})$ in the presence of competing anions such as phosphate $\left(\mathrm{PO}_{4}{ }^{3-}\right)$ has decreased adsorption, as $\mathrm{P}$ tends to cause specific adsorption by inner-sphere complexes, hindering ion exchange [32]. However, in the present study, where each element was added individually to the straw, and where phosphate was not added, phosphate sorption did not take place on wheat straw. In fact, wheat straw released $37.7 \mathrm{mg} \mathrm{L}^{-1} \mathrm{P}$ without adding P (i.e., just adding $30 \mathrm{~mL}$ of the $1 \mathrm{M} \mathrm{NaNO}_{3}$ solution, stirring, centrifuging, filtering, and quantifying $\mathrm{P}$ using UV-visible spectroscopy (UV-1201, Shimadzu, Kyoto, Japan) (data not shown).

Table 2. Solution $\mathrm{pH}$ and DOC $\left(\mathrm{mg} \cdot \mathrm{L}^{-1}\right)$ after As, $\mathrm{Cr}, \mathrm{F}$, and Ni sorption on wheat straw, for different concentrations added $\left(\mathrm{C}_{0}\right)$.

\begin{tabular}{ccccc}
\hline $\mathbf{C}_{\mathbf{0}}$ & $\mathbf{A s}(\mathbf{V})$ & $\mathbf{C r}(\mathbf{V I})$ & $\mathbf{F}^{-}$ & $\mathbf{N i}^{\mathbf{2 +}}$ \\
\hline $\mathbf{m m o l} \cdot \mathbf{L}^{-\mathbf{1}}$ & & $\mathbf{p H}$ \\
\hline 0.5 & $7.0( \pm 0.1)$ & $6.2( \pm 0.1)$ & $8.0( \pm 0.2)$ & $5.5( \pm 0.1)$ \\
1.5 & $7.4( \pm 0.1)$ & $6.3( \pm 0.1)$ & $7.9( \pm 0.2)$ & $5.7( \pm 0.1)$ \\
3 & $7.5( \pm 0.1)$ & $6.4( \pm 0.1)$ & $7.1( \pm 0.1)$ & $5.8( \pm 0.1)$ \\
6 & $7.6( \pm 0.2)$ & $6.6( \pm 0.1)$ & $7.1( \pm 0.1)$ & $5.9( \pm 0.1)$ \\
\hline $\mathbf{m m o l} \cdot \mathbf{L}^{-\mathbf{1}}$ & \multicolumn{5}{c}{$\mathbf{D O C}\left(\mathbf{m g} \cdot \mathbf{L}^{-\mathbf{1}}\right)$} \\
\hline 0.5 & $423.2( \pm 11.5)$ & $256.4( \pm 8.3)$ & $337.8( \pm 9.2)$ & $289.5( \pm 8.7)$ \\
1.5 & $494.3( \pm 14.2)$ & $272.3( \pm 8.7)$ & $355.4( \pm 9.4)$ & $213.6( \pm 6.8)$ \\
3.0 & $486.0( \pm 13.8)$ & $298.3( \pm 9.1)$ & $379.9( \pm 10.1)$ & $192.2( \pm 5.9)$ \\
6.0 & $487.6( \pm 13.6)$ & $319.3( \pm 9.4)$ & $403.3( \pm 11.6)$ & $158.6( \pm 5.1)$ \\
\hline
\end{tabular}

Note: Average values ( \pm standard deviation) for 3 replicates, with coefficients of variation always $<5 \%$.

Regarding $\mathrm{Cr}(\mathrm{VI})$, strongly acidic environments promote protonation of active groups of bio-sorbents (in fact, carboxylic, hydroxyl, and amine functional groups were detected on the surface of this wheat straw-see Supplementary Materials, as well as Coelho et al. [17]), which will acquire positive charges and attract anionic $\mathrm{Cr}(\mathrm{VI})$ species $\left(\mathrm{HCrO}_{4}{ }^{-}, \mathrm{Cr}_{2} \mathrm{O}_{7}{ }^{2-}\right.$, and $\left.\mathrm{CrO}_{4}{ }^{2-}\right)$ [33]. For the wheat straw here studied, the $\mathrm{pH}$ values in the equilibrium solutions were not strongly acidic, suffering an increase from 6.1 to 6.6. However, these values are acidic enough to be below its $\mathrm{pH}_{\text {PZC }}(6.68)$, suggesting a predominance of positive charges on the surface of the adsorbent material, although it did not allow for a high $\mathrm{Cr}(\mathrm{VI})$ sorption efficiency.

For $\mathrm{As}(\mathrm{V})$ and $\mathrm{Cr}(\mathrm{VI})$, an increase in the $\mathrm{pH}$ of the equilibrium solution took place as the added concentration of these elements increased. The same was observed by Fernández-Pazos et al. [25] 
studying chromium sorption and by Seco-Reigosa et al. [11] studying arsenic sorption. This behavior may occur when the samples adsorb $\mathrm{Cr}(\mathrm{VI})$ and $\mathrm{As}(\mathrm{V})$ predominantly by electrostatic attraction between the adsorbent surface and the anionic species of these elements, releasing $\mathrm{OH}^{-}$and causing an increase in $\mathrm{pH}[10,34,35]$. In the present study, some $\mathrm{pH}$ increases took place even when 3 and $6 \mathrm{mmol} \mathrm{L}^{-1} \mathrm{As}(\mathrm{V})$ were added (with no $\mathrm{As}(\mathrm{V})$ sorption taking place on straw for these added concentrations), suggesting that additional causes could contribute to raising $\mathrm{pH}$.

In the case of $\mathrm{F}, \mathrm{pH}$ decreased from 8.0 to 7.1 in the equilibrium solution (Table 2). However, these $\mathrm{pH}$ values are above the $\mathrm{pH}_{\mathrm{PZC}}$ of wheat straw (6.68), which causes a dominance of negative charges on the surface of the sorbent (as in the case of As), and this could reduce $\mathrm{F}^{-}$ sorption. Some studies reported the release of $\mathrm{OH}^{-}$during the adsorption of $\mathrm{F}^{-}$, which caused an increase in $\mathrm{pH}[29,34,36]$. However, this did not occur in the present study with wheat straw, with a slight acidification of the environment and variable reduction of DOC levels taking place in the solution with increasing concentrations of added $\mathrm{F}$. The absence of $\mathrm{pH}$ increases can be explained by $\mathrm{F}^{-}$sorption taking place by means of $\mathrm{H}$ bonds or van der Waals forces, without the release of $\mathrm{OH}^{-}$ groups $[35,37,38]$. Another possibility is the formation of precipitates including $\mathrm{F}^{-}$and different elements present in wheat straw, resulting in complexes such as $\mathrm{CaF}_{2}$ or TiF [39]. Organic matter can adsorb $\mathrm{F}^{-}$through polyvalent cations or through $\mathrm{H}$ bonds, which can justify the absence of increase of DOC in solution (Table 2).

For $\mathrm{Ni}^{2+}$, increasing concentrations added were associated with increasing $\mathrm{pH}$ values in the equilibrium solutions (although always being below the $\mathrm{pH}_{\mathrm{PZC}}$ value of wheat straw, thus favoring positive surface charges, which made sorption of $\mathrm{Ni}^{2+}$ difficult) and with decreasing $\mathrm{DOC}$ values. The progressive $\mathrm{pH}$ increase could be due to cationic exchange releasing basic cations such as $\mathrm{Ca}^{2+}$ and $\mathrm{Mg}^{2+}$ from the surface of the sorbent, cations that could facilitate precipitation of organic matter (carboxylic acids were detected on this wheat straw-see Supplementary Materials) and the subsequent decrease in DOC values.

\section{2. $\mathrm{As}(\mathrm{V}), \mathrm{Cr}(\mathrm{VI}), \mathrm{F}^{-}$and $\mathrm{Ni}^{2+}$ Sorption Curves}

Sorption curves are presented in Figure 2. As in Figure 1, these plots show almost a total absence of retention in the case of $\mathrm{As}$, rather high sorption for $\mathrm{Ni}$ and $\mathrm{F}$, and moderate sorption for $\mathrm{Cr}$. The layouts of $\mathrm{Ni}, \mathrm{F}$, and $\mathrm{Cr}$ show a linear trend, without signs of stabilization.

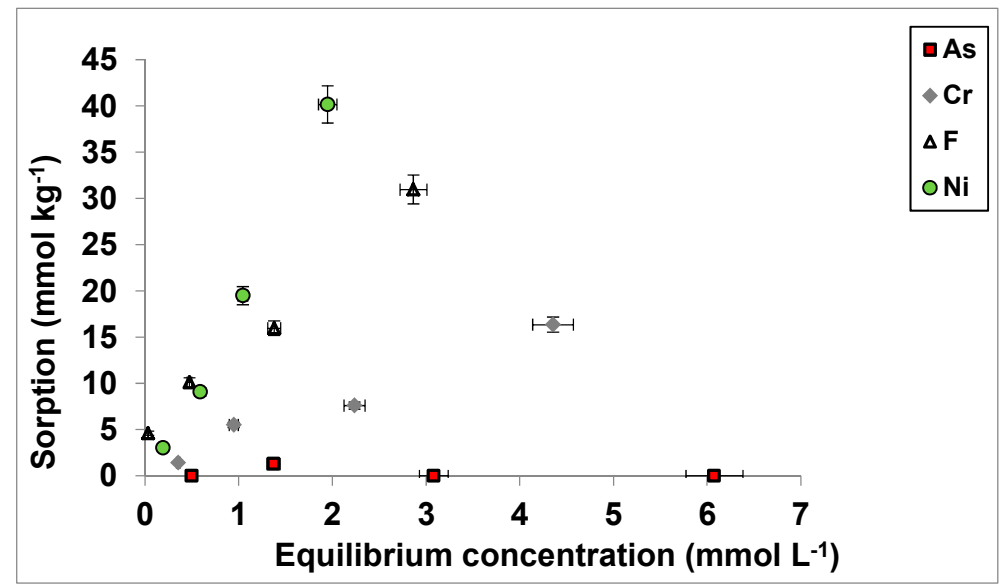

Figure 2. Sorption curves for As, Cr, F, and Ni. Average values (with error bars) for 3 replicates, with coefficients of variation always $<5 \%$.

Accordingly, the fitting of sorption data was not possible in the case of the Langmuir model due to error values being too high for adjustment. The parameters of the Freundlich model are shown in 
Table 3. The satisfactory fitting of $\mathrm{Cr}, \mathrm{F}$, and Ni data to the Freundlich model suggests multilayer-type adsorption on wheat straw for these elements.

Table 3. Parameters of the Freundlich model related to sorption on wheat straw.

\begin{tabular}{cccc}
\hline Pollutant & $\boldsymbol{K}_{\boldsymbol{F}}\left(\mathbf{m m o l} \cdot \mathbf{k g}^{-\mathbf{1}}\right)$ & $\boldsymbol{n}$ & $\boldsymbol{R}^{\mathbf{2}}$ \\
\hline $\mathrm{As}$ & - & - & - \\
$\mathrm{Cr}$ & $4.3 \pm 0.7$ & $0.89 \pm 0.13$ & 0.978 \\
$\mathrm{~F}$ & $15.1 \pm 1.7$ & $0.65 \pm 0.12$ & 0.970 \\
$\mathrm{Ni}$ & $18.2 \pm 0.3$ & $1.19 \pm 0.03$ & 0.999 \\
\hline \multicolumn{4}{c}{ Note: -: error values too high for fitting. }
\end{tabular}

Note: -: error values too high for fitting.

Corroborating previous findings mentioned above, Table 3 shows that $\mathrm{K}_{\mathrm{F}}$ values follow the sequence $\mathrm{Ni}>\mathrm{F}>\mathrm{Cr}$, whereas the order of the Freundlich n parameter was $\mathrm{Ni}>\mathrm{Cr}>\mathrm{As}$, with only that of $\mathrm{Ni}$ being $>1$. The $\mathrm{n}$ parameter indicates the reactivity of the active sites of the adsorbent, which is related to its heterogeneity. According to Khezami and Capart [40], and Foo and Hameed [41], values of $n>1$ are a strong indication of the presence of high energy sites. These values can also suggest the occurrence of cooperative sorption, involving strong interactions between the molecules of the adsorbate itself.

\subsection{As, Cr, F, and Ni Desorption from Wheat Straw}

Table 4 shows high F desorption, which can be due to weak bonds such as van der Waals forces. In the opposite side, the lowest desorption corresponded to $\mathrm{Ni}$, which can be related to the strong affinity that cationic metals have with the carboxyl groups present in the adsorbent [42].

Table 4. As, Cr, F, and Ni desorption in $\mathrm{mmol} \cdot \mathrm{L}^{-1}$ (and $\mathrm{mmol} \cdot \mathrm{kg}^{-1}$ between brackets) from wheat straw for different concentrations added.

\begin{tabular}{|c|c|c|c|c|}
\hline $\mathrm{C}_{0}$ & As & $\mathrm{Cr}$ & F & $\mathrm{Ni}$ \\
\hline $\mathrm{mmol} \cdot \mathrm{L}^{-1}$ & \multicolumn{4}{|c|}{ Desorption } \\
\hline 0.5 & $0.17(1.74)$ & $0.14(1.39)$ & $0.23(2.24)$ & $0.10(0.99)$ \\
\hline 1.5 & $0.60(5.99)$ & $0.46(4.59)$ & $0.55(5.40)$ & $0.28(2.81)$ \\
\hline 3.0 & - & $0.92(9.19)$ & 1.58 (15.65) & $0.53(5.31)$ \\
\hline 6.0 & - & $2.29(22.76)$ & $3.51(34.67)$ & $1.06(10.51)$ \\
\hline
\end{tabular}

Notes: Average values for 3 replicates, with coefficients of variation always $<5 \%$; -: experiment not performed due to an absence of sorption.

Table 5 shows alkalization of the solution when the elements were desorbed, suggesting that $\mathrm{OH}^{-}$ was released in parallel with these elements. DOC in solution increased with $\mathrm{Cr}$ and $\mathrm{F}$ desorption (which can be in relation to the facilitated release of organic matter due to alkalization) and decreased with $\mathrm{Ni}$ desorption (probably in relation to precipitation of organo-metal compounds).

In the present work, desorption studies mainly focused on the retention of the studied pollutants on wheat straw; however, additional research would be needed to deepen an understanding of the mechanism involved, especially if regeneration of the sorbent is a main objective. 
Table 5. $\mathrm{pH}$ and DOC in equilibrium solutions after As, $\mathrm{Cr}, \mathrm{F}$, and Ni desorption from wheat straw.

\begin{tabular}{ccccc}
\hline $\mathbf{C}_{\mathbf{0}}$ & $\mathbf{A s}$ & $\mathbf{C r}$ & $\mathbf{F}$ & $\mathbf{N i}$ \\
\hline $\mathbf{m m o l} \cdot \mathbf{L}^{-\mathbf{1}}$ & \multicolumn{4}{c}{$\mathbf{p H}$} \\
\hline 0.5 & $6.24( \pm 0.1)$ & $5.74( \pm 0.1)$ & $5.45( \pm 0.1)$ & $5.51( \pm 0.1)$ \\
1.5 & $6.14( \pm 0.1)$ & $5.77( \pm 0.1)$ & $5.54( \pm 0.1)$ & $5.65( \pm 0.1)$ \\
3.0 & - & $6.16( \pm 0.1)$ & $5.6( \pm 0.1) 0$ & $5.50( \pm 0.1)$ \\
6.0 & - & $6.35( \pm 0.1)$ & $6.19( \pm 0.2)$ & $5.8( \pm 0.1)$ \\
$\mathbf{C}_{\mathbf{0}}$ & $\mathbf{A s}$ & $\mathbf{C r}$ & $\mathbf{F}$ & $\mathbf{N i}$ \\
\hline $\mathbf{m m o l}^{-\mathbf{L}^{-1}}$ & \multicolumn{4}{c}{$\mathbf{D O C}\left(\mathbf{m g} \cdot \mathbf{L}^{-\mathbf{1}}\right)$} \\
\hline 0.5 & $194.7( \pm 8.4)$ & $108.5( \pm 4.1)$ & $114.7( \pm 3.8)$ & $111.2( \pm 2.7)$ \\
1.5 & $249.2( \pm 9.6)$ & $121.0( \pm 4.3)$ & $127.6( \pm 3.2)$ & $114.2( \pm 3.1)$ \\
3.0 & - & $216.3( \pm 6.9)$ & $135.0( \pm 4.2)$ & $115.5( \pm 2.9)$ \\
6.0 & - & $249.0( \pm 6.7)$ & $168.9( \pm 4.9)$ & $80.8( \pm 1.2)$ \\
\hline
\end{tabular}

Notes: Average values ( \pm standard deviation) for 3 replicates, with coefficients of variation always $<5 \%$; -: experiment not performed due to absence of sorption.

\subsection{Implications of the Research}

In this work, it was found that wheat straw sorption potential is rather high for $\mathrm{Ni}$ and $\mathrm{F}$ (which could be useful in cases of pollution due to these elements), whereas it was low for $\mathrm{Cr}(\mathrm{VI})$, and almost non-existent for $\mathrm{As}(\mathrm{V})$. Wheat straw has also previously shown its potential to retain $\mathrm{Cd}^{2+}, \mathrm{Cu}^{2+}$, and $\mathrm{Pb}^{2+}$ [17], which would be an additional aid to control the eventual pollution episodes due to these elements.

Further future research could focus on alternatives to solve wheat straw's low efficacy regarding $\mathrm{Cr}(\mathrm{VI})$ and $\mathrm{As}(\mathrm{V})$ immobilization. In this way, the utilization of complementary bio-sorbents would be interesting. Specifically, pine bark could be used to retain $\mathrm{Cr}(\mathrm{VI})[26,27]$, whereas mussel shell could be used to facilitate $\mathrm{As}(\mathrm{V})$ retention [28]. Some studies have also dealt with the retention of pollutants on wheat straw, although under conditions different from those of the present work. These studies, collectively, have used carbonized wheat straw to remove up to $99.9 \% \mathrm{Cr}(\mathrm{VI})$ at $\mathrm{pH} 1$ [43], used neuro-fuzzy techniques to predict the removal capacity of $\mathrm{Cu}(\mathrm{II})$ and $\mathrm{Cr}(\mathrm{VI})$ from aqueous solutions by wheat straw [44], investigated $\mathrm{Ni}(\mathrm{II})$ and $\mathrm{Zn}$ (II) bio-sorption potential of sulfuric-acid-treated wheat straw by means of column experiments [45], reviewed the efficacy of wheat straw as a bio-sorbent for As removal (finding up to $3.8 \mathrm{mg} \cdot \mathrm{g}^{-1}$ in modified straw) [46], and reviewed the bio-sorption of heavy metals on wheat-straw-based materials [47], finding up to $87.8 \% \mathrm{Cr}(\mathrm{VI})$ removal at $\mathrm{pH} 2$, and up to $12.0 \mathrm{mg} \cdot \mathrm{g}^{-1} \mathrm{Ni}$ removal at $\mathrm{pH}$. This means that other alternatives to the use of complementary bio-sorbents could be taken into account in order to increase pollutants removal, when working conditions can be safe and effectively changed in this way. Future works should also focus on used (as sorbent) wheat straw management. Finally, additional future research is needed to reach a deeper understanding of the sorption mechanism taking place on wheat straw, as previously carried out in other studies performed by different authors, whose focuses have included iron oxide nanoparticles [48], biochar [49], flower powder [50], biomass [51], microbial bio-sorbents [52], and various other bio-sorbents [53,54].

\section{Conclusions}

In this work, where batch-type experiments were used to study $\mathrm{As}(\mathrm{V}), \mathrm{Cr}(\mathrm{VI}), \mathrm{F}^{-}$, and $\mathrm{Ni}^{2+}$ sorption/desorption on/from wheat straw, $\mathrm{Ni}^{2+}$ showed notable sorption $(60.7 \%$ and $67.5 \%$ when 3 and 6 mmol L ${ }^{-1} \mathrm{Ni}$ were added); it was rather high for $\mathrm{F}^{-}$(from 52.3\% to 93.4\%), rather low for $\mathrm{Cr}(\mathrm{VI})$ (maximum of 36.9\%), and almost non-existent for $\mathrm{As}(\mathrm{V})$. The satisfactory fitting of $\mathrm{Cr}, \mathrm{F}$, and $\mathrm{Ni}$ data to the Freundlich model suggests multilayer-type adsorption on wheat straw for these elements. The lowest desorption corresponded to Ni, whereas it was high for $\mathrm{F}$. The results of this research could aid to program the appropriate use of wheat straw as a bio-sorbent, especially in cases where 
$\mathrm{Ni}$ and/or F concentrations are too high. It could be also relevant in agricultural soils where straw is recycled, or in soils suffering from forest fires and exposure to high erosion risks, where straw mulching is frequently applied, and when peaks of runoff pollution take place. At the laboratory scale, different aspects could be subjects of further research that focuses on wheat straw used as a bio-sorbent, such as the competitive sorption of anions, or even the effects of the simultaneous presence of both anions and cations, as well as the effects of changing environmental conditions such as temperature, $\mathrm{pH}$, ionic strength, and incubation time.

Supplementary Materials: The following are available online at www.mdpi.com/2073-4441/9/9/690/s1. Table S1: Results of the chemical characterization of the wheat straw used. Average values for 3 replicates, with coefficients of variation always $<5 \%$ ); Figure S1: Infrared spectrum of wheat straw.

Acknowledgments: Funds received to perform this study: grant numbers CGL2012-36805-C02-01 and CGL2012-36805-C02-02 (Ministerio de Economía y Competitividad, Government of Spain). The European Regional Development Fund (ERDF) partially financed it. We have not received funds for covering the costs to publish in open access.

Author Contributions: Aurora Romar-Gasalla, Gustavo F. Coelho, Juan Carlos Nóvoa-Muñoz, Manuel Arias-Estévez, María J. Fernández-Sanjurjo, Esperanza Álvarez-Rodríguez, and Avelino Núñez-Delgado conceived and designed the experiments; Aurora Romar-Gasalla and Gustavo F. Coelho performed the experiments; Aurora Romar-Gasalla, Gustavo F. Coelho, Juan Carlos Nóvoa-Muñoz, Manuel Arias-Estévez, María J. Fernández-Sanjurjo, Esperanza Álvarez-Rodríguez, and Avelino Núñez-Delgado analyzed the data; Aurora Romar-Gasalla, Gustavo F. Coelho, Juan Carlos Nóvoa-Muñoz, Manuel Arias-Estévez, María J. Fernández-Sanjurjo, Esperanza Álvarez-Rodríguez, and Avelino Núñez-Delgado wrote the paper.

Conflicts of Interest: The authors declare no conflict of interest. The founding sponsors had no role in the design of the study; in the collection, analyses, or interpretation of data; in the writing of the manuscript; or in the decision to publish the results.

\section{References}

1. Smith, E.; Naidu, R.; Alston, A.M. Arsenic in the soil environment, a review. Adv. Agron. 1998, 64, 149-195. [CrossRef]

2. Zhang, L.; Qin, X.; Tang, J.; Liu, W.; Yang, H. Review of arsenic geochemical characteristics and its significance on arsenic pollution studies in karst groundwater, Southwest China. Appl. Geochem. 2016, 77, 80-88. [CrossRef]

3. He, L.; Wang, M.; Zhang, G.; Qiu, G.; Cai, D.; Wu, Z.; Zhang, X. Remediation of Cr(VI) contaminated soil using long-duration sodium thiosulfate supported by micro-nano networks. J. Hazard. Mater. 2015, 294, 64-69. [CrossRef] [PubMed]

4. Rawajfih, Z.; Nsour, N. Thermodynamic analysis of sorption isotherms of chromium (VI) anionic species on reed biomass. J. Chem. Thermodyn. 2008, 40, 846-851. [CrossRef]

5. Loganathan, P.; Hedley, M.J.; Wallace, G.C.; Roberts, A.H.C. Fluoride accumulation in pasture forages and soils following long-term applications of phosphorus fertilizers. Environ. Pollut. 2001, 115, 275-282. [CrossRef]

6. Yesilnacar, M.I.; Yetis, A.D.; Dülgergil, C.T.; Kumral, M.; Atasoy, A.D.; Dogan, T.R.; Tekiner, S.I.; Bayhan, I.; Aydogdu, M. Geomedical assessment of an area having high-fluoride groundwater in southeastern Turkey. Environ. Earth 2016, 75, 162-175. [CrossRef]

7. Matraszek, R.; Hawrylak-Nowak, B.; Chwil, S.; Chwil, M. Macronutrient composition of nickel-treated wheat under different sulfur concentrations in the nutrient solution. Environ. Sci. Pollut. Res. 2016, 23, 5902-5914. [CrossRef] [PubMed]

8. Núñez-Delgado, A.; Álvarez-Rodríguez, E.; Fernández-Sanjurjo, M.J.; Nóvoa-Muñoz, J.C.; Arias-Estévez, M.; Fernández-Calviño, D. Perspectives on the use of by-products to treat soil and water pollution. Microporous Mesoporous Mater. 2015, 210, 199-201. [CrossRef]

9. Quintáns-Fondo, A.; Ferreira-Coelho, G.; Paradelo-Núñez, R.; Nóvoa-Muñoz, J.C.; Arias-Estévez, M.; Fernández-Sanjurjo, M.J.; Álvarez-Rodríguez, E.; Núñez-Delgado, A. Promoting sustainability in the mussel industry: Mussel shell recycling to fight fluoride pollution. J. Clean. Prod. 2016, 131, 485-490. [CrossRef] 
10. Otero, M.; Cutillas-Barreiro, L.; Nóvoa-Muñoz, J.C.; Arias-Estévez, M.; Fernández-Sanjurjo, M.J.; Álvarez-Rodríguez, E.; Núñez-Delgado, A. Cr(VI) sorption/desorption on untreated and mussel-shell-treated soil materials: Fractionation and effects of $\mathrm{pH}$ and chromium concentration. Solid Earth 2015, 6, 373-382. [CrossRef]

11. Seco-Reigosa, N.; Bermúdez-Couso, A.; Garrido-Rodríguez, B.; Arias-Estévez, M.; Fernández-Sanjurjo, M.J.; Álvarez-Rodríguez, E.; Núñez-Delgado, A. As(V) retention on soils and forest by-products and other waste materials. Environ. Sci. Pollut. Res. 2013, 20, 6574-6583. [CrossRef] [PubMed]

12. Seco-Reigosa, N.; Cutillas-Barreiro, L.; Nóvoa-Muñoz, J.C.; Arias-Estévez, M.; Fernández-Sanjurjo, M.J.; Álvarez-Rodríguez, E.; Núñez-Delgado, A. Mixtures including wastes from the mussel shell processing industry: Retention of arsenic, chromium and mercury. J. Clean. Prod. 2014, 84, 680-690. [CrossRef]

13. Núñez-Delgado, A.; Fernández-Sanjurjo, M.J.; Álvarez-Rodríguez, E.; Cutillas-Barreiro, L.; Nóvoa-Muñoz, J.C.; Arias-Estévez, M. Cr(VI) Sorption/Desorption on Pine Sawdust and Oak Wood Ash. Int. J. Environ. Res. Public Health 2015, 12, 8849-8860. [CrossRef] [PubMed]

14. Malik, D.S.; Jain, C.K.; Yadav, A.K. Removal of heavy metals from emerging cellulosic low-cost adsorbents: A review. Appl. Water Sci. 2016, 7, 1-24. [CrossRef]

15. Searle, S.Y.; Malins, C.J. Waste and residue availability for advanced biofuel production in EU Member States. Biomass Bioenergy 2016, 89, 2-10. [CrossRef]

16. Tye, Y.Y.; Lee, K.T.; Abdullah, W.N.W.; Leh, C.P. The world availability of non-wood lignocellulosic biomass for the production of cellulosic ethanol and potential pretreatments for the enhancement of enzymatic saccharification. Renew. Sustain. Energy Rev. 2016, 60, 155-172. [CrossRef]

17. Coelho, G.F.; GonÇalves, A.C., Jr.; Nóvoa-Muñoz, J.C.; Fernández-Calviño, D.; Arias-Estévez, M.; Fernández-Sanjurjo, M.J.; Álvarez-Rodríguez, E.; Núñez-Delgado, A. Competitive and non-competitive cadmium, copper and lead sorption/desorption on wheat straw affecting sustainability in vineyards. J. Clean. Prod. 2016, 139, 1496-1503. [CrossRef]

18. Doan, H.D.; Lohi, A.; Dang, V.B.H.; Dang-Vu, T. Removal of $\mathrm{Zn}^{+2}$ and $\mathrm{Ni}^{+2}$ by adsorption in a fixed bed of wheat straw. Process Saf. Environ. Prot. 2008, 86, 259-267. [CrossRef]

19. Fernández, C.; Vega, J.A. Are erosion barriers and straw mulching effective for controlling soil erosion after a high severity wildfire in NW Spain? Ecol. Eng. 2016, 87, 132-138. [CrossRef]

20. Vega, J.A.; Fernández, C.; Fonturbel, T. Comparing the effectiveness of seeding and mulching + seeding in reducing soil erosion after a high severity fire in Galicia (NW Spain). Ecol. Eng. 2015, 74, 206-212. [CrossRef]

21. Dang, V.B.H.; Doan, H.D.; Dang-Vu, T.; Lohi, A. Equilibrium and kinetics of biosorption of cadmium(II) and copper(II) ions by wheat straw. Bioresour. Technol. 2009, 100, 211-219. [CrossRef] [PubMed]

22. Mahmood-ul-Hassan, M.; Suthar, V.; Rafique, E.; Ahmad, R.; Yasin, M. Kinetics of cadmium, chromium, and lead sorption onto chemically modified sugarcane bagasse and wheat straw. Environ. Monit. Assess. 2015, 187, 470. [CrossRef] [PubMed]

23. Pehlivan, E.; Altun, T.; Parlayıc1, S. Utilization of barley straws as biosorbents for $\mathrm{Cu}^{2+}$ and $\mathrm{Pb}^{2+}$ ions. J. Hazard. Mater. 2009, 164, 982-986. [CrossRef] [PubMed]

24. Rao, Z.; Huang, D.; Zhu, H.; Zhu, Q.H.; Wang, J.Y.; Luo, Z.C.; Xu, C.; Shen, X.; He, Y.B. Effect of rice straw mulching on migration and transportation of $\mathrm{Cd}, \mathrm{Cu}, \mathrm{Zn}$, and $\mathrm{Ni}$ in surface runoff under simulated rainfall. J. Soils Sediments 2016, 16, 2021-2029. [CrossRef]

25. Fernández-Pazos, M.T.; Garrido-Rodríguez, B.; Nóvoa-Muñoz, J.C.; Arias-Estévez, M.; Fernández-Sanjurjo, M.J.; Núñez-Delgado, A.; Álvarez, E. Cr(VI) adsorption and desorption on soils and bio-sorbents. Water Air Soil Pollut. 2013, 224, 1-12. [CrossRef]

26. Quintáns-Fondo, A.; Ferreira-Coelho, G.; Paradelo-Núñez, R.; Nóvoa-Muñoz, J.C.; Arias-Estévez, M.; Fernández-Sanjurjo, M.J.; Álvarez-Rodríguez, E.; Núñez-Delgado, A. As(V)/Cr(VI) pollution control in soils, hemp waste and other by-products: Competitive sorption trials. Environ. Sci. Pollut. Res. 2016, 23, 19182-19192. [CrossRef] [PubMed]

27. Paradelo, R.; Conde-Cid, M.; Arias-Estévez, M.; Nóvoa-Muñoz, J.C.; Álvarez-Rodríguez, E.; Fernández-Sanjurjo, M.J.; Núñez-Delgado, A. Removal of anionic pollutants by pine bark is influenced by the mechanism of retention. Chemosphere 2017, 167, 139-145. [CrossRef] [PubMed]

28. Seco-Reigosa, N.; Cutillas-Barreiro, L.; Nóvoa-Muñoz, J.C.; Arias-Estévez, M.; Álvarez-Rodríguez, E.; Fernández-Sanjurjo, M.J.; Núñez-Delgado, A. Adsorption, desorption and fractionation of $\mathrm{As}(\mathrm{V})$ on untreated and mussel shell-treated granitic material. Solid Earth 2015, 6, 337-346. [CrossRef] 
29. Gago, C.; Romar, A.; Fernández-Marcos, M.L.; Álvarez, E. Fluoride sorption and desorption on soils located in the surroundings of an aluminium smelter in Galicia (NW Spain). Environ. Earth Sci. 2014, 72, 4105-4114. [CrossRef]

30. Castillo, A.M.N.; Soriano, J.J.; García-Delgado, R.A. Changes in chromium distribution during the electrodialytic remediation of Cr (VI)-contaminated soil. Environ. Geochem. Health 2008, 30, 153-157. [CrossRef] [PubMed]

31. Mohan, D.; Pittman, C.U. Arsenic removal from water/wastewater using adsorbents—A critical review. J. Hazard. Mater. 2007, 142, 1-53. [CrossRef] [PubMed]

32. Cui, H.; Li, Q.; Gao, S.A.; Shang, J.K. Strong adsorption of arsenic species by amorphous zirconium oxide nanoparticles. J. Ind. Eng. Chem. 2012, 18, 1418-1427. [CrossRef]

33. Ucun, H.; Bayhan, Y.K.; Kaya, Y.; Cakici, A.; Algur, O.F. Biosorption of chromium (VI) from aqueous solution by cone biomass of Pinus sylvestris. Bioresour. Technol. 2002, 85, 155-158. [CrossRef]

34. Gago, C.; Romar, A.; Fernández-Marcos, M.L.; Álvarez, E. Fluorine sorption by soils developed from various parent materials in Galicia (NW Spain). J. Colloid Interface Sci. 2012, 374, 232-236. [CrossRef] [PubMed]

35. Valdivieso, A.L.; Bahena, J.L.R.; Song, S.; Urbina, R.H. Temperature effect on the zeta potential and fluoride adsorption at the $\alpha-\mathrm{Al}_{2} \mathrm{O}_{3}$ /aqueous solution interface. J. Colloid Interface Sci. 2006, 298, 1-5. [CrossRef] [PubMed]

36. Arnesen, A.K.M.; Krogstad, T. Sorption and desorption of fluoride in soil polluted from the aluminium smelter at Ardal in Western Norway. Water Air Soil Pollut. 1998, 103, 357-373. [CrossRef]

37. Boddu, V.; Krishnaiah, A.; Talbot, J.; Smith, E. Removal of hexavalent chromium from wastewater using a new composite chitosan biosorbent. Environ. Sci. Technol. 2003, 37, 4449-4456. [CrossRef] [PubMed]

38. Harrington, L.F.; Cooper, E.N.; Vasudevan, D. Fluoride sorption and associated aluminum release in variable charge soil. J. Colloid Interface Sci. 2003, 267, 302-313. [CrossRef]

39. Mohan, D.; Pittman, C.U.; Mohan, D.; Sharma, R.; Sing, V.K.; Steele, P.; Pitman, C.U. Fluoride removal from water using bio-char, a Green waste, low-cost adsorbent: Equilibrium uptake and sorption dynamics modelling. Ind. Eng. Chem. Res. 2012, 51, 900-914. [CrossRef]

40. Khezami, L.; Capart, R. Removal of chromium (VI) from aqueous solution by activated carbons: Kinetic and equilibrium studies. J. Hazard. Mater. 2005, 123, 223-231. [CrossRef] [PubMed]

41. Foo, K.Y.; Hameed, B.H. Insights into the modeling of adsorption isotherm systems. Chem. Eng. J. 2010, 156, 2-10. [CrossRef]

42. Krishnami, K.K.; Meng, X.; Christodoulatos, B.; Boddum, V.M. Biosorption mechanism of nine different heavy metals onto biomatrix from rice husk. J. Hazard. Mater. 2008, 153, 1222-1234. [CrossRef] [PubMed]

43. Song, D.; Pan, K.; Tariq, A.; Azizullah, A.; Sun, F.; Li, Z.; Xiong, Q. Adsorptive Removal of Toxic Chromium from Waste-Water Using Wheat Straw and Eupatorium adenophorum. PLoS ONE 2016, 11, e0167037. [CrossRef] [PubMed]

44. Rebouh, S.; Bouhedda, M.; Hanini, S. Neuro-fuzzy modeling of $\mathrm{Cu}(\mathrm{II})$ and $\mathrm{Cr}(\mathrm{VI})$ adsorption from aqueous solution by wheat straw. Desalin. Water Treat. 2015, 57, 1-16. [CrossRef]

45. Booran, S.K.; Doan, H.D.; Lohi, A. Recovery of Zn(II) and Ni(II) Binary from Wastewater Using Integrated Biosorption and Electrodeposition. Clean Soil Air Water 2015, 43, 368-374. [CrossRef]

46. Shakoor, M.B.; Niazi, N.K.; Bibi, I.; Murtaza, G.; Kunhikrishnan, A.; Seshadri, B.; Shahid, M.; Ali, S.; Bolan, N.S.; Ok, Y.S.; et al. Remediation of arsenic-contaminated water using agricultural wastes as biosorbents. Crit. Rev. Environ. Sci. Technol. 2016, 46, 467-499. [CrossRef]

47. Farooq, U.; Kozinski, J.A.; Khan, M.A.; Athar, M. Biosorption of heavy metal ions using wheat based biosorbents-A review of the recent literature. Bioresour. Technol. 2010, 101, 5043-5053. [CrossRef] [PubMed]

48. Lingamdinne, L.P.; Chang, Y.Y.; Yang, J.K.; Singh, J.; Choi, E.H.; Shiratani, M.; Koduru, J.R.; Attri, P. Biogenic reductive preparation of magnetic inverse spinel iron oxide nanoparticles for the adsorption removal of heavy metals. Chem. Eng. J. 2017, 307, 74-84. [CrossRef]

49. Ahmad, M.; Rajapaksha, A.U.; Lim, J.E.; Zhang, M.; Bolan, N.; Mohan, D.; Vithanage, M.; Lee, S.S.; Ok, Y.S. Biochar as a sorbent for contaminant management in soil and water: A review. Chemosphere 2014, 99, 19-33. [CrossRef] [PubMed]

50. Lingamdinne, L.P.; Koduru, J.R.; Jyothi, R.K.; Chang, Y.Y.; Yang, J.K. Factors affect on bioremediation of Co(II) and $\mathrm{Pb}(\mathrm{II})$ onto Lonicera japonica flowers powder. Desalin. Water Treat. 2016, 57, 13066-13080. [CrossRef] 
51. Lesmana, S.O.; Febriana, N.; Soetaredjo, F.E.; Sunarso, J.; Ismadji, S. Studies on potential applications of biomass for the separation of heavy metals from water and wastewater. Biochem. Eng. J. 2009, 44, $19-41$. [CrossRef]

52. Ayangbenro, A.S.; Babalola, O.O. A New Strategy for Heavy Metal Polluted Environments: A Review of Microbial Biosorbents. Int. J. Environ. Res. Public Health 2017, 14, 94. [CrossRef] [PubMed]

53. Wang, J.; Chen, C. Biosorbents for heavy metals removal and their future. Biotechnol. Adv. 2009, 27, $195-226$. [CrossRef] [PubMed]

54. Fu, F.; Wang, Q. Removal of heavy metal ions from wastewaters: A review. J. Environ. Manag. 2011, 92, 407-418. [CrossRef] [PubMed]

(C) 2017 by the authors. Licensee MDPI, Basel, Switzerland. This article is an open access article distributed under the terms and conditions of the Creative Commons Attribution (CC BY) license (http:/ / creativecommons.org/licenses/by/4.0/). 